\title{
Life cycle assessment during packaging of market-sized seabass and meagre: necessary adaptations toward GHG neutrality
}

\author{
Evangelos Konstantinidis ${ }^{1,2}\left(\right.$ Costas Perdikaris $^{1} \cdot$ Konstantinos Ganias $^{2}$
}

Received: 3 October 2019 / Accepted: 11 June 2021 / Published online: 22 June 2021

(c) The Author(s), under exclusive licence to Springer-Verlag GmbH Germany, part of Springer Nature 2021

\begin{abstract}
Purpose Fish is a delicate and valuable source of protein, and aquaculture is expected to provide the required amount of fish needed at reasonable prices. Packaging is a vital stage to preserve hygiene, quality and freshness of aquaculture products. The purpose of this study was to identify environmental hotspots in farmed seabass and meagre during the packaging stage and to examine scenarios for reducing environmental impacts, aiming at greenhouse gas neutrality.

Methods The life cycle assessment method was applied for the first time at three packaging plants of farmed seabass and meagre in western Greece, in order to assess their environmental impacts, taking into account the amount of electricity, expanded polystyrene, and other plastic and packaging materials needed. Moreover, different scenarios were designed involving the energy mix/alternative sources, recycling and reuse of packaging materials, and the replacement of standard polystyrene boxes and wooden pallets, in order to suggest environmentally friendly improvements in the packaging process. Results and discussion Conventional operation of seabass and meagre packaging plants requires significant amounts of energy and packaging materials. In fact, electricity, boxes and pallets were documented as the main contributors to most of the environmental impact indicators. Seabass packaging had a slightly lower overall environmental impact compared to meagre, due to its smaller market size. Impact minimization scenarios resulted in various degrees of reduction of environmental burdens in both species; however, near-zero GHG emissions were achieved when energy from photovoltaic panels and recycling/reuse of packaging materials were combined with the use of non-fossil-based boxes and recyclable pallets. Such readily applicable adjustments to the conventional operation of packaging plants would contribute to overall environmental sustainability and to better consumer acceptability of the final product.

Conclusions In a nutshell, the life cycle assessment method proved to be a valuable tool for assessing the environmental performance of Mediterranean aquaculture packaging processes. Moreover, it served to identify critical factors directly related to the EU GHG neutrality target. Accordingly, environmentally friendly decision-making/strategic management in the farmed fish packaging sector will inevitably rely on alternative energy sources, recycling of packaging materials, and use of recyclable corrugated board boxes or similar non-fossil-based materials.
\end{abstract}

Keywords Life cycle assessment $\cdot$ Packaging plants $\cdot$ Seabass $\cdot$ Meagre $\cdot$ Fish size $\cdot$ Environmental impact scenarios $\cdot$ GHG neutrality

\section{Introduction}

Population growth and rising living standards in developing

Communicated by Hans-Jürgen Garvens.

Evangelos Konstantinidis

vkonstandin@yahoo.com

1 Department of Fisheries, Regional Unit of Thesprotia, Region of Epirus, 46100 Igoumenitsa, Greece

2 School of Biology, Aristotle University of Thessaloniki, 54124 Thessaloniki, Greece countries are increasing global demand for food and animalderived protein (Boland et al. 2013). Accordingly, growing competition for land, water, and energy not only affects the ability to produce food but also calls for environmental impact reduction in food production systems (Godfray et al. 2010). Fish and seafood are increasingly important sources of protein for the growing world population. In developing countries, seafood is often the major source of protein 
for people (FAO 2018) and it is promoted as a sustainable alternative to red meat that, for environmental and health reasons, is recommended to be restricted in a balanced diet (Scarborough et al. 2014; Tilman and Clark 2014; WCRF/ AICR 2018; Hallström et al. 2019).

Intensive marine fish farming in the Mediterranean Sea and particularly in Greece has a 37-year old successful record, with gilthead sea bream (Sparus auratus Linnaeus, 1758) and Mediterranean seabass (Dicentrarchus labrax Linnaeus, 1758) production reaching $120,500 \mathrm{t}$ in 2019. Minor volumes of around 4,300 $t$ of the total production consist of promising candidate species such as meagre (Argyrosomus regius Asso, 1801; FGM 2020). The majority of the production is channelled to certified packaging plants, and since fish farms are located several miles from the markets, packaging plays important roles; it maintains hygiene conditions and freshness, ensures traceability, and most importantly, reduces product losses and achieves extension of shelf-life of the final product (Williams 2011).

Expanded polystyrene (EPS), a lightweight thermoplastic (Brox et al. 1984) is one of the dominant and most widespread materials used for packaging farmed fish. EPS is produced from a hydrocarbon monomer called styrene (Tan and Khoo 2005), which subsequently is expanded up to 40 times its original size using pentane gas $\left(\mathrm{C}_{5} \mathrm{H}_{12}\right)$ or carbon dioxide $\left(\mathrm{CO}_{2}\right)$. Under the action of heat, it can be molded into any kind of shape (EUMEPS 2009) and hardens as it cools. The unique characteristics of EPS are as follows: (a) extremely lightweight material made of $98 \%$ air; (b) easy of transfer; (c) once hardened, its strength is comparable to wood; (d) it is unaffected by moisture; and e) it has very good resistance to heat conductivity (Hall 2011). It is resistant to "thermal shock" (i.e., sudden changes in temperature during transit or storage), which makes it ideal for food packaging and transportation, for fish products to maintain the cool chain, in particular.

Although thermoplastics are involved in many applications from a user perspective, criticism has been raised due to health risks arising from styrene leaking compounds (FAO 2016) and potentially negative environmental effects, mostly related to the end-of-life treatment of these fossilbased materials (North and Halden 2013; Saraiva et al. 2016). As a result, the use of such materials in packaging products is becoming an environmental issue (Thrane et al. 2009). Similarly, the energy consumption and the energy mix issues related to environmental impacts are at the core of scientific, public, and policy attention. Notably, it is estimated that $15 \%$ of the electricity consumed worldwide is used for refrigeration (Coulomb 2008).

Levin et al. (2015) presented in detail the concept of greenhouse gas emission neutrality, which was introduced in the draft Paris Agreement at that time: "Greenhouse gas (GHG) emissions neutrality should be interpreted to mean net zero anthropogenic GHG emissions from all sectors. It is achieved first and foremost by reducing total GHG emissions to as close to zero as possible. Any remaining GHGs would be balanced with an equivalent amount of removals (such as enhanced sequestration in the land sector) or negative emissions (possibly using future technologies like bioenergy combined with carbon capture and sequestration." Subsequently, on 28 November 2018, the European Commission presented its strategic long-term vision for a prosperous, modern, competitive, and climate-neutral economy by 2050 (EC 2018a). The Commission's vision for a climate-neutral future covers nearly all EU policies and is in line with the Paris Agreement objective to keep global temperature increase to well below $2{ }^{\circ} \mathrm{C}$ and pursue efforts to keep it to $1.5^{\circ} \mathrm{C}$ by 2050 . To stabilize global temperature, $\mathrm{CO}_{2}$ and greenhouse gas (GHGs) emissions have to be netzero or close to it (Evans and Pidcock 2015). GHGs do not have a direct effect on human or ecosystem health. However, many of the processes that emit GHGs are also responsible for emissions of other air pollutants that cause environmental problems, such as air quality degradation, acidification, and eutrophication, causing damage to ecosystems with the consequent loss of biodiversity and human health problems (e.g., respiratory and cardiovascular) (RCN 2050 2019).

Within the above context, life cycle assessment (LCA) tool can be used for quantitative assessment of the materials, energy flows and impacts of a production system and evaluation of the environmental performance of products and/ or services. It is an Environmental Management standards series technique (ISO:14000 family and specifically ISO 14044, 14046) of the International Organization for Standardization (ISO 2006a, b). It takes into account a product's life cycle; from the extraction of resources, processing of raw materials, production, use, possible recycling, to the final disposal of remaining wastes. In brief, LCA is a material and energy balance application, combined with environmental assessment of the impacts related to the inputs and the outputs of a production system. From this point of view, LCA provides criteria for decision-making on issues such as environmental product development, policy making and strategic planning. It has been promoted in European directives as a robust quantitative tool and a keystone in decision-making for producers and stakeholders. It can also be used for comparisons between hypothetical scenarios of the relative efficiencies of production procedures (Pelletier et al. 2007).

LCA is increasingly used as a suitable method of assessing the environmental impacts in fish farming (Bohnes et al. 2019; Konstantinidis et al. 2019). To date, available published works involving application of the LCA method during the packaging stage (but not exclusively focused on that part of the process) are mainly related to fish processing (i.e., filleting, smoking, canning) of the following species: sardine 
(Almeida et al. 2015), tuna (Avadi et al. 2015), anchovy (Laso et al. 2017), cod (Ziegler et al. 2003; Svanes et al. 2011; Margeirsson et al. 2012), hake (Vázquez-Rowe et al. 2011), herring and mackerel (Thrane et al. 2009), horse mackerel (Vázquez-Rowe et al. 2010), salmon (Buchpies et al. 2011), haddock (Claussen et al. 2011), rainbow trout (Gronroos et al. 2006; Silvenius et al. 2017), tilapia (Pelletier and Tyedmers 2010), and shrimp (Cao et al. 2011; Ziegler et al. 2011). Most of these species represent wild catches either processed on-board in factory-fishing vessels or processed after landing at fishing ports. Only two farmed species of Mediterranean origin (i.e., the Mediterranean mussel and turbot) (Iribarren et al. 2010, 2012), both in Galicia, Spain, involved LCA in the packaging stage, but only as part of the entire farming cycle assessment.

Accordingly, the aim of this gate-to-gate study was as follows: (a) to identify the environmental impact hotspots in fresh farmed fish (seabass and meagre) exclusively during the packaging stage; (b) to compare these two species taking into account their typical marketing weight differences; and (c) to examine reasonable scenarios for environmental impact minimization at packaging plant level, ideally targeting GHG neutrality.

\section{Materials and methods}

\subsection{LCA inventory, functional unit, and system boundaries}

Raw data were acquired from three packaging plants following ISO 14044 principles with similar infrastructure and equipment, located in NW Greece. Data were collected during the same period in 2016-2018 and involved 12,046.38 t of packaged fish (Table 1).

The typical market size for farmed seabass is around $0.4 \mathrm{~kg}$, while the typical size for meagre is much bigger, around $2.0-2.5 \mathrm{~kg}$. Seabass was packaged in various sizes of EPS boxes with different capacities: 3 and $5 \mathrm{~kg}$ (open), 5,6 , and $8 \mathrm{~kg}$ (with a lid). Approximately $2.3 \mathrm{~kg}$ (38\% in $6 \mathrm{~kg}$ boxes) and $4.5 \mathrm{~kg}$ ( $43 \%$ in $10 \mathrm{~kg}$ boxes) of flake ice are needed for seabass and meagre, respectively, based on the

Table 1 Amount of packaged fish and EPS boxes used from packaging plants

\begin{tabular}{lcl}
\hline & $\begin{array}{l}\text { Weighed packaged } \\
\text { fish (t) }\end{array}$ & $\begin{array}{l}\text { Used EPS } \\
\text { boxes } \\
\text { (items) }\end{array}$ \\
\hline Packaging plant A & $3,438.86$ & 653,500 \\
Packaging plant B & $2,296.17$ & 446,504 \\
Packaging plant C & $6,311.35$ & 952,966 \\
Total & $12,046.38$ & $2,052,970$ \\
\hline
\end{tabular}

total weight of the EPS boxes. For meagre, the weight range of boxes is higher: $10,13,15$, and $18 \mathrm{~kg}$, all closed with a lid. The most commonly used boxes have a holding capacity of $6 \mathrm{~kg}$ for seabass and $10 \mathrm{~kg}$ for meagre. The mean weight of packaged seabass was $5.73 \mathrm{~kg}$, while for meagre it was $10.67 \mathrm{~kg}$.

Similarly to other published works (e.g., Wikström et al. 2014; Avadí et al. 2015), the functional unit (FU) is $1 \mathrm{t}$ of farmed fish fully packaged at plant exit. Although the current work is about fish packaging and the obvious functional unit could have been one individual package, the variety of EPS packages (i.e., weight capacity) and the presence of two different species led us to select a functional unit based on biomass in order to allow comparison of the two species. The definition of system boundary is critical for the assessment of environmental impacts associated with inputs and outputs, and the results of LCA are highly dependent on the product system defined (Mungkung and Gheewala 2007). The system boundaries of this gate-to-gate study included the packaging procedure from the import of isothermal bins, filled with harvested fish and ice, into the packaging plant, up to the exit of $1 \mathrm{t}$ of fully packaged fish (Fig. 1).

After the farming and harvesting stages, the fish are transported in isothermal bins to the packaging plants. The bins are filled with fish and ice. Inside the packaging plant, the bins are overturned and the fish are forwarded to the production line that consists of automatic grading, batching and weighing machine where fish are sorted into appropriate sizes. The production line, which runs on compressed air and electricity, channels the fish to the appropriate gates (based on size) where they are manually placed into EPS boxes.

The next step is to place a low-density polyethylene (LDPE) film on top of the fish to avoid direct contact with flake ice, which may cause thermal burns on the skin of the fish. Adding ice to the EPS box helps to maintain the cool chain at the required temperature. Moreover, ice has an additional function; it keeps the fish moist and retains their fresh appearance. All three examined packaging plants had indoor flake ice production machines.

The subsequent packaging stage consists of affixing labels on each box, wrapping them with polypropylene (PP) sealing tape and, finally, piling the boxes on a palette and covering it with stretch film (LDPE). As regards the wood needed for transportation, 95\% of Euro palettes are reused while the remaining 5\% (taken into consideration for calculations) are either destroyed or lost (i.e., waste) during transportation. Finally, the "ready to go" palettes are placed by handoperated forklift in a freezer before being loaded onto refrigerated trucks (at the exit gate of the packaging plant), for further transportation/distribution to the markets.

The described process has a lot in common with other onshore fresh fish packaging plants in Europe. For example, the basic weighing, batching, packaging, and palletizing line 


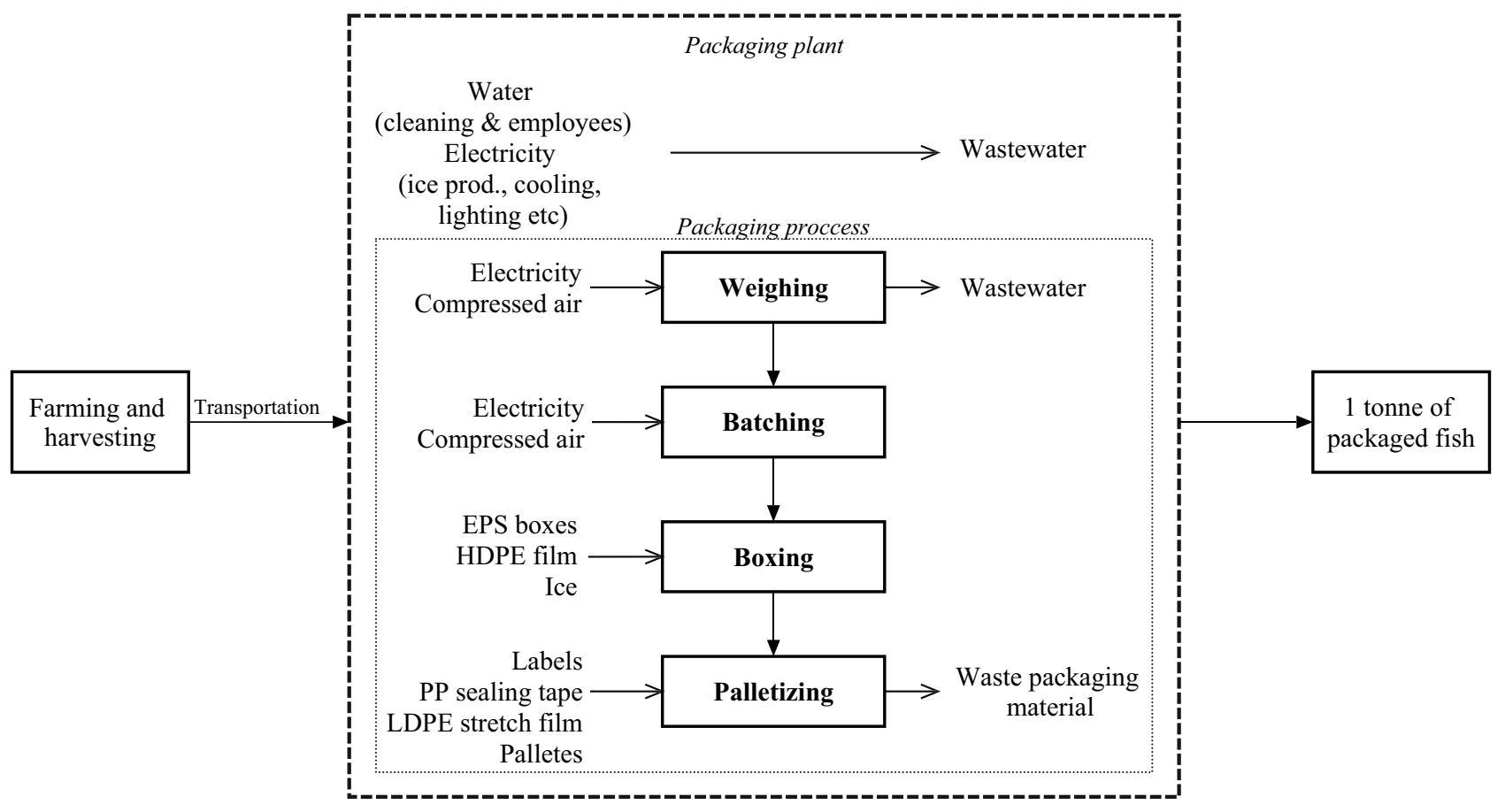

Fig. 1 Packaging process of farmed seabass and meagre. System boundaries are presented with dotted line

leading to fixed-weight packs, with a capacity of up to 125 fish/minute, is similar to that used in whitefish and salmon primary processing (i.e., excluding further processing such as evisceration, skinning, beheading, filleting, deboning, and slicing) (Eilertsen 2012; Marel 2012).

In all the previous stages, energy is needed to maintain an appropriate low temperature in the packaging plant, as well as water for (a) cleaning the packaging plant, (b) employee needs (wastewater), and (c) production of ice. The waste paper from the packaging material (i.e., stretch film and sealing tape rolls) and the waste/destroyed EPS boxes (Table 2) were also involved in the calculations.

In most LCA studies, infrastructure, capital goods, and equipment such as machinery and buildings are excluded from the calculations (Mungkung and Gheewala 2007; Roma et al. 2015). This assumption is usually made due to the fact that environmental impacts involved can be neglected, based on the lifespan of these facilities (i.e., long periods of amortization). As a result, only machinery maintenance is taken into account (i.e., refrigeration, air compressor, and electronic equipment).

The impact assessment/calculation method selected was the ReCiPe 2016 (H) (both at midpoint and endpoint level). The midpoint calculation method, which addresses 18 impact categories (Table 3), was selected because it is problem-oriented, thus allowing for the identification of specific environmental hotspots (Huijbregts et al. 2016) during the packaging procedure. On the other hand, the use of the endpoint method was applied in order to shed light on the relative importance of impact categories. Concerning the "climate change" impact category, midpoint refers to a

Table 2 Life cycle inventory of $1 \mathrm{t}$ packaged seabass and meagre (main inputs and outputs/averages from three packaging plants)

\begin{tabular}{llll}
\hline & Sea bass & Meagre & Unit \\
\hline Inputs & & & \\
Ice & 0.370 & 0.426 & $\mathrm{~m}^{3}$ \\
Electricity (GR energy mix)* & 93.11 & 93.11 & $\mathrm{KW}$ \\
Expanded polystyrene (EPS) & 28.505 & 37.002 & $\mathrm{~kg}$ \\
Pallet (Euro-pallet) & 2.004 & 2.082 & $\mathrm{p}$ \\
Plastic labels (polyethylene) & 0.168 & 0.094 & $\mathrm{~kg}$ \\
Stretch film (low-density polyethylene) & 1.002 & 1.041 & $\mathrm{~kg}$ \\
Sealing tape (polypropylene) & 0.146 & 0.152 & $\mathrm{~kg}$ \\
Plastic film (low-density polyethylene) & 0.451 & 0.251 & $\mathrm{~kg}$ \\
Computers (use) & 40 & 40 & $\mathrm{~min}$ \\
Air compressor (maintenance)* & 1 & 1 & $\mathrm{p}$ \\
Refrigeration machines (maintenance)* & 5 & 5 & $\mathrm{p}$ \\
Outputs & & & \\
Waste paper (rolls) & 0.251 & 0.260 & $\mathrm{~kg}$ \\
Waste water (ice from bins) & 0.526 & 0.666 & $\mathrm{~m} 3$ \\
Waste water (cleaning and employees) & 0.230 & 0.230 & $\mathrm{~m} 3$ \\
Waste EPS* & 0.518 & 0.518 & $\mathrm{~kg}$ \\
Waste wood (from pallet) & 2.204 & 2.290 & $\mathrm{~kg}$ \\
Waste steel (from pallet) & 0.019 & 0.020 & $\mathrm{~kg}$ \\
BOD (5) & 850 & 833 & $\mathrm{mg}$ \\
\hline
\end{tabular}

* Data refer to whole working time of the packaging plant 
Table 3 The 18 impact categories of Recipe 2016 (H) midpoint

\begin{tabular}{llll}
\hline Impact category & Symbol & Impact category & Symbol \\
\hline Global warming & GW & Terrestrial ecotoxicity & TEx \\
Stratospheric ozone depletion & SOzD & Freshwater ecotoxicity & FEx \\
Ionizing radiation & IRad & Marine ecotoxicity & MEx \\
Ozone formation, human health & OzFHH & Human carcinogenic toxicity & HCTx \\
Fine particulate matter formation & FPMF & Human non-carcinogenic toxicity & HnCTx \\
Ozone formation, terrestrial ecosystems & OzFTE & Land use & LU \\
Terrestrial acidification & TAc & Mineral resource scarcity & MRSc \\
Freshwater eutrophication & FEu & Fossil resource scarcity & FRSc \\
Marine eutrophication & MEu & Water consumption & WC \\
\hline
\end{tabular}

100-year timeframe, as this is the basis adopted by the Kyoto Protocol I (EC-JRC 2011). All calculations were performed with SimaPro, ver. 9.0 (PRé Sustainability BV, Netherlands) using the EcoInvent (ver. 3.5; Wernet et al. 2016) and the ELCD (JRC-EU) databases.

\subsection{Scenarios applied for reducing environmental impacts}

After calculating the overall environmental impact for each fish size and comparing them, different impact reduction scenarios were generated and compared with conventional packaging:

a) Scenario A: Replacement of Greece's energy mix (relying mainly on lignite) by the European average mix;

b) Scenario B: Replacement of the electricity energy mix with energy produced exclusively by solar photovoltaic panels;

c) Scenario C: Total (100\%) recycling/reuse of EPS and packaging materials (i.e., sealing tape, stretch film, plastic film, wooden pallet) and waste treatment;

d) Scenario D: Replacement of the electricity energy mix with energy produced exclusively by solar photovoltaic panels, use of corrugated board boxes (instead of EPS) and reusable HDPE pallets, recycling of the rest packing materials (i.e., sealing tape, stretch film, plastic film) and waste treatment. In this scenario, commercially available $10 \mathrm{~kg}$ and $20 \mathrm{~kg}$ boxes made of corrugated board, filled with $2.5 \mathrm{~kg}$ and $5 \mathrm{~kg}$ ice, respectively, were assessed for seabass and meagre, respectively. Moreover, due to the smaller external dimensions of corrugated boxes (i.e., approximately $6 \mathrm{~cm}$ shorter in height compared to EPS boxes), the palettes can transport $20 \%$ more product in weight terms.

\section{Results}

\subsection{Conventional packaging process}

Calculations for each fish species of different sizes were made in order to identify the main factors contributing to environmental impacts. The use of electricity and EPS boxes, followed by pallets, were the most prominent factors affecting environmental indicators in both species, with minor differences between them (Fig. 2). In particular, electricity primarily affected "human non-carcinogenic toxicity," "marine ecotoxicity," "freshwater ecotoxicity," and "freshwater eutrophication," while the use of EPS boxes was related to "fossil resource scarcity", "water consumption" and "global warming" impact categories. Finally, the "land use" impact category was almost exclusively affected by wooden pallets in both species.

A direct comparison of packaged seabass and meagre hotspot analysis showed that seabass scored lower (0.5-17.4\%) than meagre in all environmental impact categories (Fig. 3). Differences greater than $10 \%$, were documented in the "global warming", "ozone formation human health," "ozone formation, terrestrial ecosystems," and "fossil resource scarcity" categories. The most important difference was evident in the "water consumption" category. In particular, in the "global warming" and "fine particulate matter formation" categories that cause damage to the environment and human health, the differences were $13.03 \%$ and $7.18 \%$ in favor of seabass, respectively.

\subsection{Scenarios for minimizing environmental impacts}

Scenarios A, B, and C were related to the replacement of the national energy mix, the use of solar energy and finally to recycling/reuse of EPS boxes, packaging materials, as well 


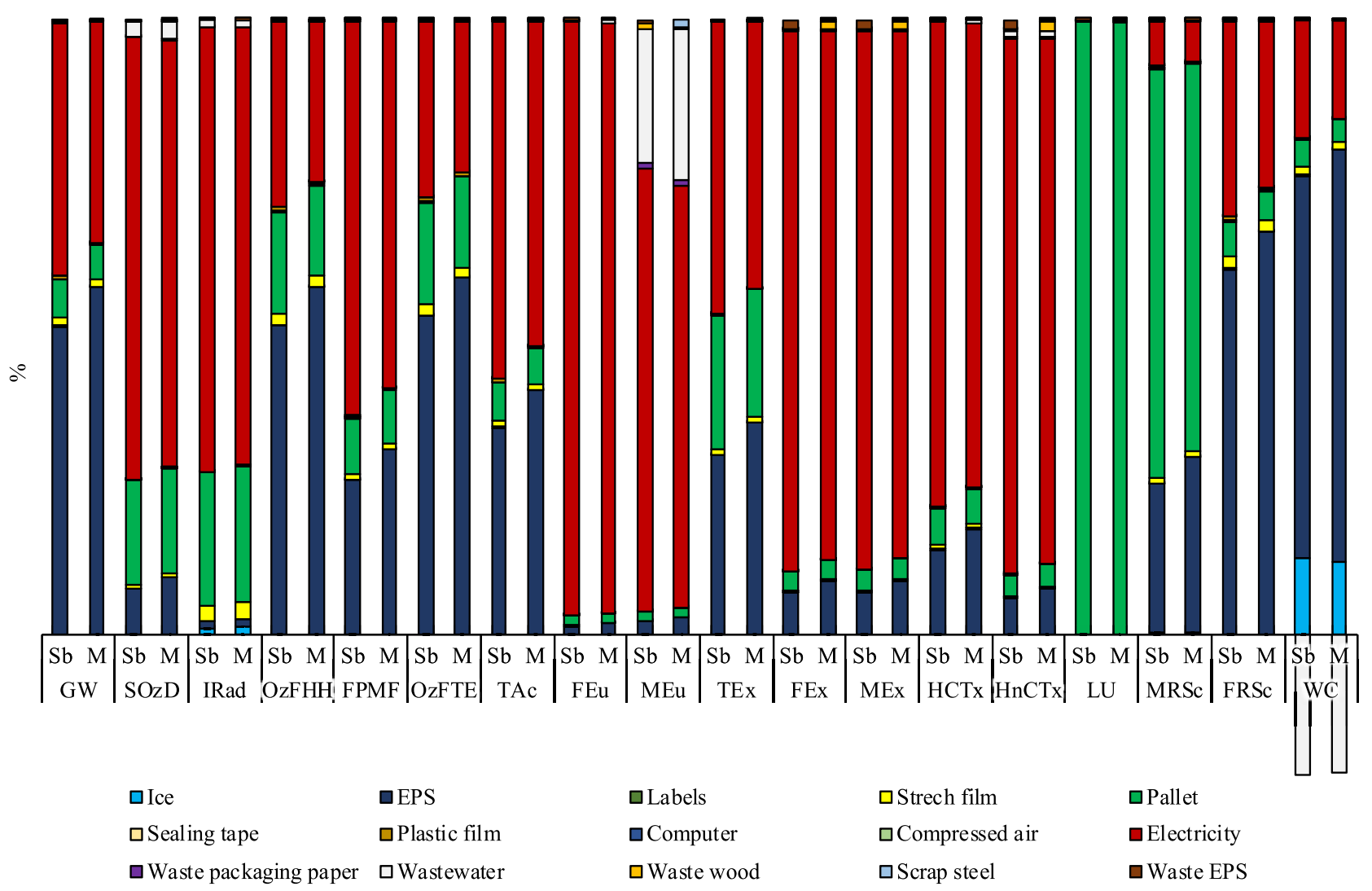

Fig. 2 Environmental impacts in conventional fresh farmed seabass (Sb) and meagre (M) packaging

as waste treatment. Concerning scenario D, it was based on a combination of energy source alteration, replacement of wooden pallets and fossil fuel-based packaging boxes and recycling of the rest of the packaging material.

Because electricity was the major contributor to environmental impact assessment, we focused on minimizing the impacts of energy production. Scenarios A (i.e., replacement of national energy mix by the European average mix) and B (i.e., replacement of the electricity energy mix with energy from solar photovoltaic panels) are shown in Fig. 4a, b. This alternative energy source/mix affected positively most impact categories in both species.

Under scenario A, all impact indicators were moderately affected, with a reduction of 8.7-79.9\% (mean reduction: $43.3 \%$ ) in seabass and $7.5-79.5 \%$ (mean reduction $41.6 \%$ ) in meagre, except for "ionizing radiation", "land use", "mineral resource scarcity" and "water consumption" in both species (Fig. 4a, b). In contrast, according to scenario $\mathrm{B}$, the reduction ranged between 2.1 and $96.6 \%$ (mean reduction: $58.1 \%$ ) for seabass and between 2.0 and 96.1\% (mean reduction: $55.2 \%$ ) for meagre. Under this scenario, the "ionizing radiation," "freshwater ecotoxicity," "marine ecotoxicity," "human non-carcinogenic toxicity," and "freshwater eutrophication" impact categories were positively affected by over $87.4 \%$ and $85.5 \%$ in seabass and meagre, respectively, compared to either conventional packaging or scenario A (Fig. 4a, b).

In scenario $C$ (i.e., recycling/reuse of the total amount of EPS boxes, packaging materials and application of waste treatment), environmental impact was lower in almost all categories, except for the "stratospheric ozone depletion," "ionizing radiation," "freshwater eutrophication," and "land use" categories in seabass (Fig. 5a). The same pattern was evident for meagre (Fig. 5b). In the positively affected categories, impacts were lower by $4.6-57.2 \%$ (mean reduction $24.3 \%$ ) for seabass and by $5.3-62.3 \%$ for meagre (mean reduction $27.5 \%$ ).

With respect to scenario $\mathrm{D}$, it was evident that the "global warming" impact category $\left(\mathrm{CO}_{2} \mathrm{~kg}\right.$, eq) was reduced by 99.4\% for seabass and by $97.27 .0 \%$ for meagre. The "land use" category was particularly affected, with a reversal of impacts from negative to positive (Fig. 6a, b), compared to all previous scenarios. Reversal, although not so pronounced, was evident in six more impact categories. However, impacts are still present in few categories, such as "stratospheric ozone depletion," "ionizing radiation," and 


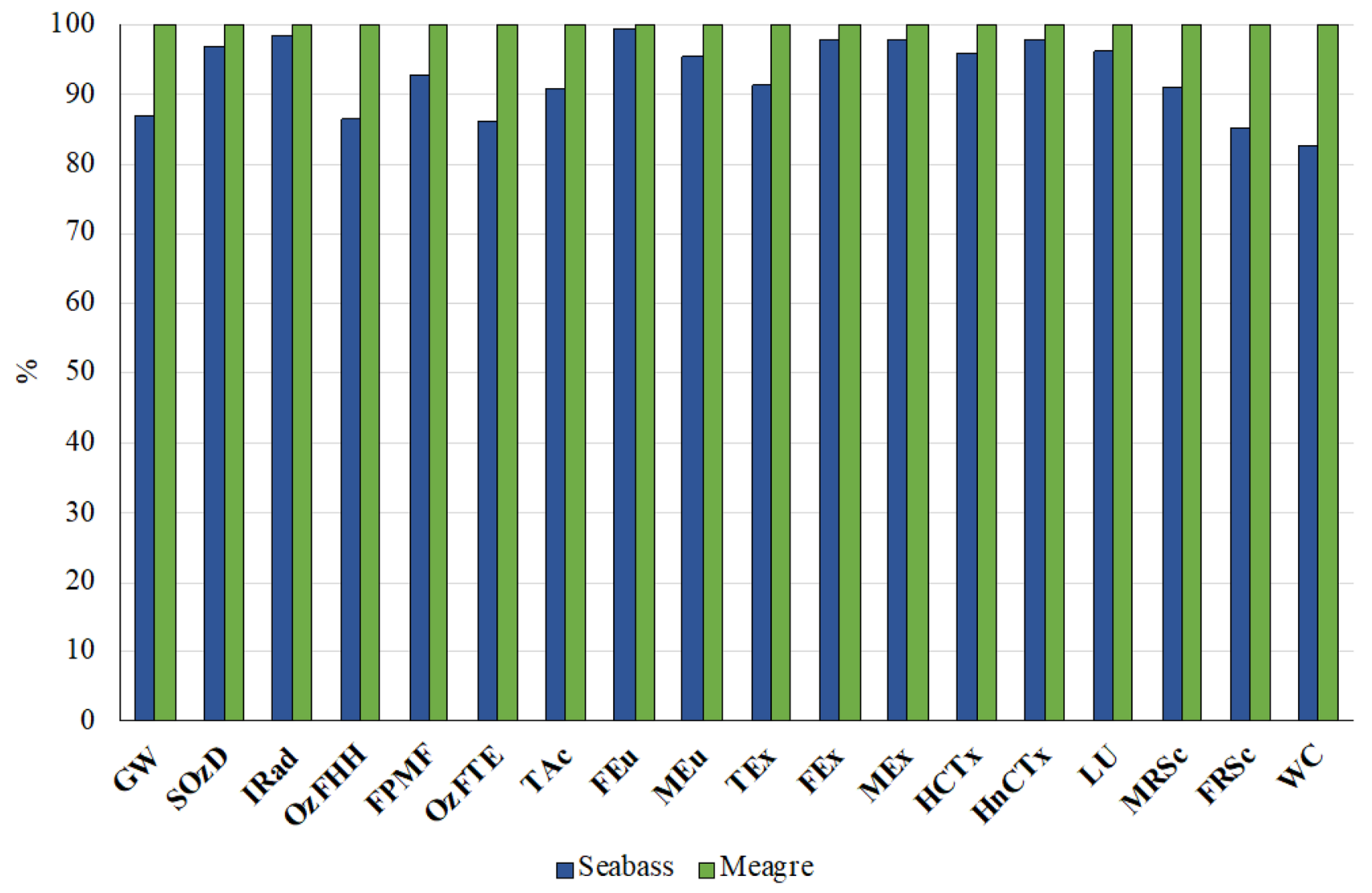

Fig. 3 LCA comparison of impacts on environmental indicators in fresh farmed seabass and meagre during conventional packaging

"mineral resource scarcity," exceeding those in conventional packaging (Fig. 6a, b) for both species.

The outcome related to the "global warming potential" category for all scenarios considered are presented and compared for both species in Fig. 7. Reductions reached $18.32 \%$, $41.18 \%, 46.72 \%$, and $99.41 \%$ for seabass and $20.02 \%$, $35.82 \%, 52.23 \%$, and $97.27 \%$ for meagre, under scenarios A, $\mathrm{B}, \mathrm{C}$, and D, respectively. Based on the endpoint calculation method, "human health" was the category primarily affected in both species, followed by damage to "ecosystems" and the "resources" category (Fig. 8). In fact, the application of scenario D led to the elimination of impacts related to the "resources" category, while impacts to "human health" decreased by $84.02 \%$ and $81.27 \%$ for seabass and meagre, respectively.

\section{Discussion}

Fish is an excellent source of protein. It is a delicate product, and packaging is vital for quality, hygiene, and safe transport and distribution to the markets. However, concerns have been raised about the environmental sustainability of the packaging process and potential impacts related to resource use and waste management. For example, the amount of packaging material associated with fishery products is significant. However, there are opportunities for waste minimization and recycling/reuse (Henningsson et al. 2004).

A comparative assessment of seabass and meagre packaging using the LCA tool in Greece revealed that the use of electricity affected most of the eighteen impact categories in both species. This was expected, given the energy-consuming nature of this process that involves ice formation, low indoor temperatures, chilling temperature for the final product in cooling chambers (prior to dispatch), operation of production line, and lighting. Additionally, Greece's energy mix currently is partly based on lignite for production, which incurs various environmental impacts. Another environmentally impacting factor was the use of non-reusable EPS boxes in vast amounts. The main ecological indicator affected was "water consumption," due to the significant volume of water needed for the production of EPS (Heikkinen et al. 2008). Moreover, the use of pallets was obviously related to "land use" due to the material used (i.e., wood and metal).

The assessment of Atlantic salmon in Australia, packaged in polystyrene boxes (Parker 2018 and references therein), accounted for a relatively small contribution of impacts during the packaging stage. Similarly, Driscoll 


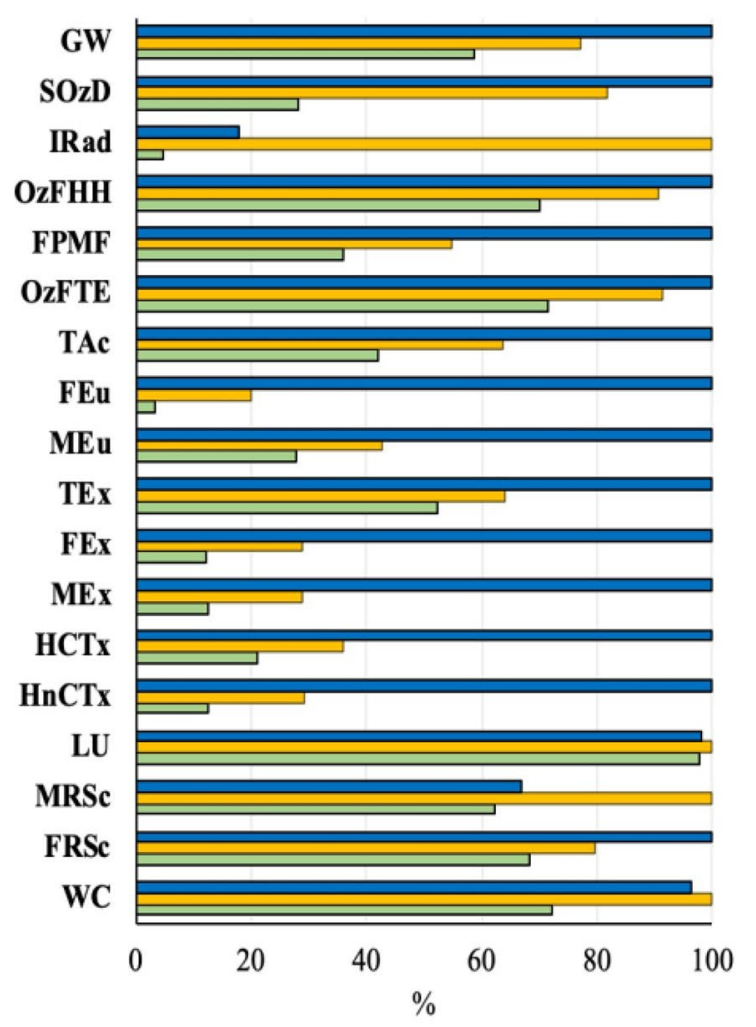

$\square$ Conventional pack. $\quad \square$ Pack. with European energy mix

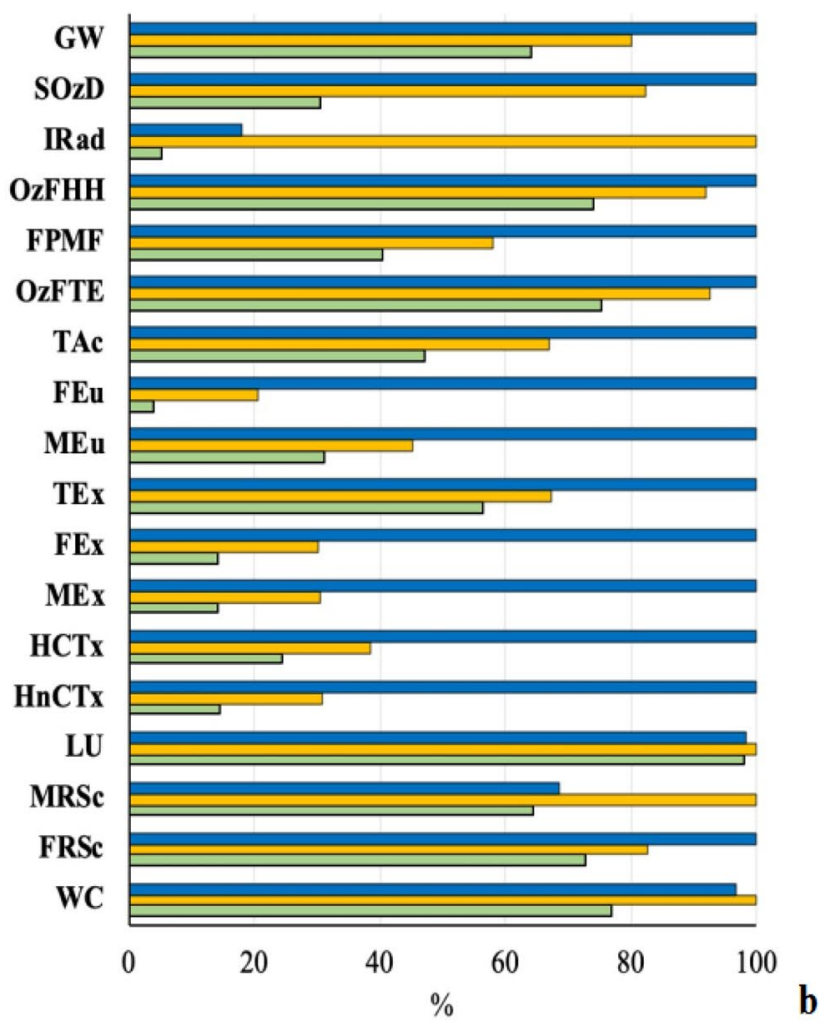

$\square$ Pack. with energy from solar PV panels

Fig. 4 LCA comparison of impacts on environmental indicators in a seabass and $\mathbf{b}$ meagre, between conventional packaging and under the scenarios $\mathrm{A}$ and $\mathrm{B}$

et al. (2015) assessed lobster air freighted from Nova Scotia/Maine to Las Vegas in polystyrene boxes and the packaging accounted for a very small portion of the impact (with the exception of ozone depletion potential). On the other hand, impacts were shown to be high in the case of canned skipjack tuna and small pelagic fish (Hospido et al. 2006; Buchspies et al. 2011). Concerning the energy inputs required for feed formulation and the on-growing stage in marine cage farms of seabass and meagre, recently published data (from the same country/production areaNW Greece; Konstantinidis et al. 2021) suggest that (a) the production of $1 \mathrm{t}$ of fish feed requires $152.24 \mathrm{~kW}$ for starter feeds, $62.53 \mathrm{~kW}$ for medium granulation feeds, and $42.70 \mathrm{~kW}$ for larger granulations, which represent the bulk of production (approximately $78 \%$ for seabass and $95 \%$ for meagre), and (b) the production of $1 \mathrm{t}$ of seabass and meagre in cage farms consumes 47.66 and $68.59 \mathrm{~kW}$ of electricity, respectively. Given that packaging requires $93.11 \mathrm{~kW}$ for each species, it is evident that a significant amount of energy is consumed for packaging. Moreover, the same work revealed that crop production and catching of wild fish for feed production cause the majority of environmental impacts of the fish farming cycle. However, these stages were out of the scope of the current gateto-gate study that focuses only on the packaging stage. Overall, the impacts caused by the packaging stage were much lower compared to the whole cycle of the products.

Differences between seabass and meagre packaging were mainly related to their market size. For example, the observed improved performance of the former species as regards "water use" can be attributed to the increased amount of ice and EPS needed for meagre per packaged EPS box. Moreover, due to the mean higher size of packaged meagre, EPS boxes are larger and heavier for extended durability and resistance. Based on the impact quantification of the product systems, the impact on "marine" and "freshwater ecotoxicity" is attributed to zinc, and the impact on "human carcinogenic toxicity" is related to chromium, both due to lignite mining spoil.

The energy issue is critical for the eco-efficiency of packaging plants. Energy consumption in Europe has increased by $1 \%$ each year during 2015-2017, thus moving away from the energy efficiency targets (3.3\% above the 2020 primary energy consumption target; Eurostat 2019). Greece was the only country that decreased its energy consumption by $2.3 \%$, during $2006-2017$, due to the economic crisis; 


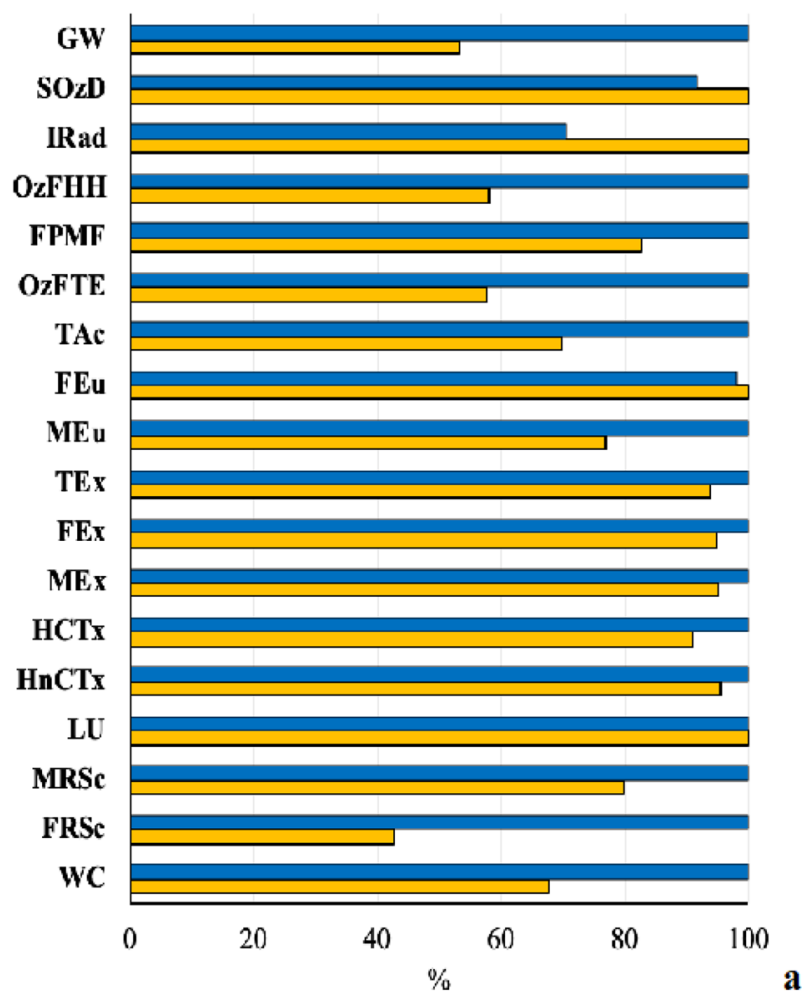

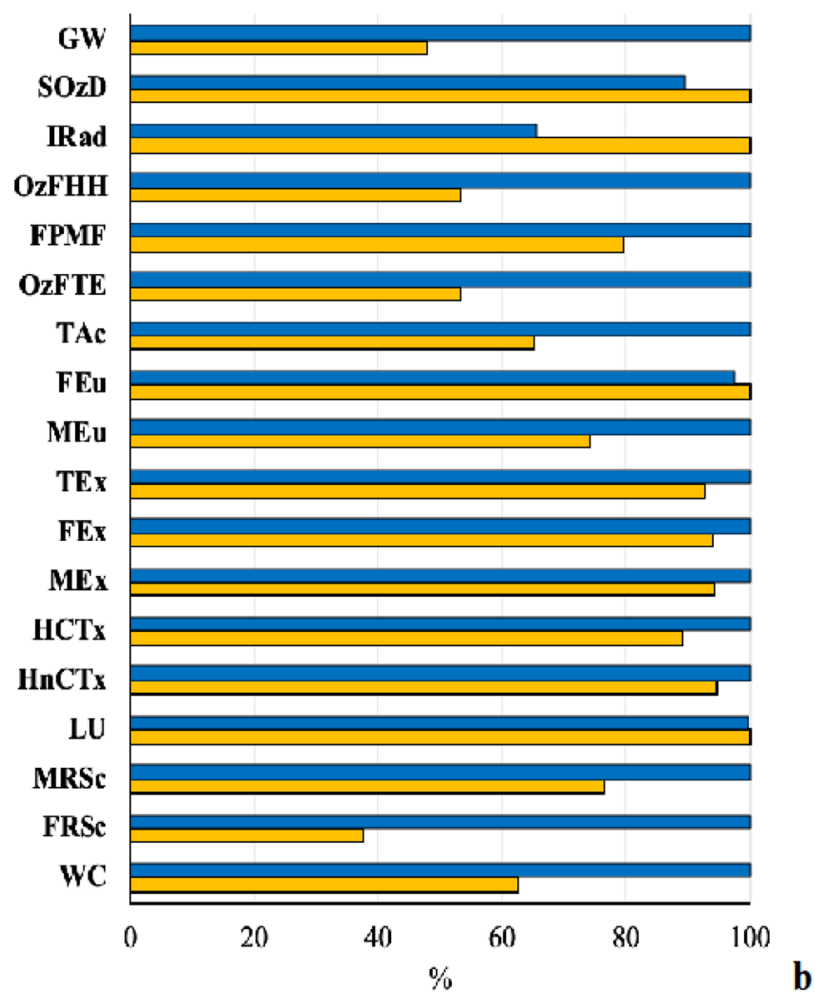

$\square$ With recycle of all pack. materials

Fig. 5 LCA comparison of impacts on environmental indicators in a seabass and $\mathbf{b}$ meagre, between conventional packaging and under the scenario $\mathrm{C}$

however, its energy mix is partly based on lignite $(29.5 \%)$, followed by natural gas $(27.8 \%)$, renewable sources $(17.4 \%)$, and hydropower (8.2\%) (Angelopoulos et al. 2017), which in turn produces negative environmental impacts. Accordingly, the applied scenario of replacing the national energy mix with Europe's "cleaner" mix, resulted in substantial improvements in most ecological indicators involved $(43.3 \%$ and $41.6 \%$ on average for both assessed species). The only exceptions were the "ionizing radiation," "marine resource scarcity" (due to the use of uranium), and "water consumption" (due to the water needed for cooling of nuclear power plants) impact categories.

While an energy mix change is a long-term strategic target, diversification in energy sources can be accomplished at packaging plant or even at sector level. The most relevant method consists in using renewable energy sources (i.e., solar photovoltaic panels). Such an option resulted in better ecological performance $(58.1 \%$ and $55.2 \%$ on average for seabass and meagre, respectively) compared either to the conventional operation of the plant or the energy mix replacement scenario. The "land use" impact category was affected most, mainly due to the extraction of silica and copper (Fthenakis et al. 2008) and the space requirements for installation of solar panels.

Five to 13 million tons of plastics (1.5-4\% of global plastics production; Siracusa et al. 2008) end up in the oceans every year (Jambeck et al 2015). It is estimated that plastic accounts for over $80 \%$ of marine litter. At the same time, land filling and incineration rates of plastic waste are still high in Europe (31\% and 39\%, respectively) reflecting a nonsustainable practice (Brems et al. 2012). Considering that $39.9 \%$ of plastic produced in Europe in 2013 was directed to the packaging sector (EC 2018b), it is obvious that the amount of plastic waste should be turned into an opportunity not only for reducing the costs but also for enhancing sustainability. Packaging boxes must be designed based not only on the price, lifetime, food safety, or practicality but also environmental sustainability (Leceta et al. 2013; Siracusa et al. 2014; Zampori and Dotelli 2014).

Currently, EPS is the most commonly used polymer in the food industry, which contributes most to environmental impacts (Williams 2011). The proposed scenario for recycling/reuse of the entire array of waste packaging material as well as waste treatment, contributed to a greater extent 

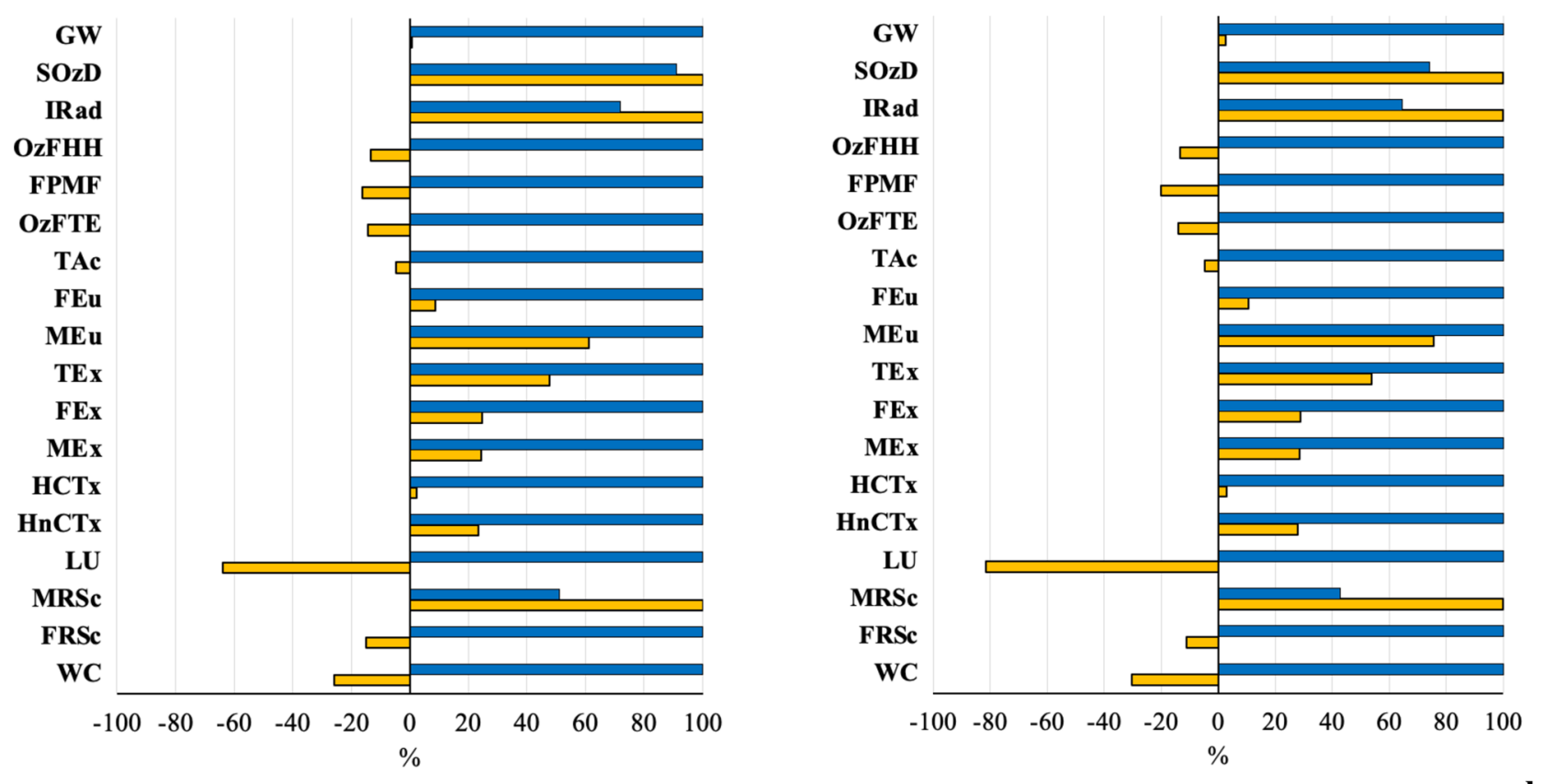

- Conventional pack.

$\square$ With energy from solar PV panels, use of corrugated boxes \& reusable pallets and recycling of the rest pack. materials

Fig. 6 LCA comparison of impacts on environmental indicators in a seabass and $\mathbf{b}$ meagre, between conventional packaging and under scenario $\mathrm{D}$

(24.3\% and $27.5 \%$ on average for seabass and meagre, respectively) to the eco-efficiency of the plants, compared to the previously examined scenarios. Like many plastics, polystyrene biodegrades slowly but it is $100 \%$ recyclable. Several previous studies have indicated that recycling is the best management option for plastic wastes (Rajendran et al. 2012; North and Halden 2013; Saraiva et al. 2016). The recovery of EPS is of great importance since its use has a short lifespan, and it produces high volumes of waste. Samper et al. (2010) proposed that it can be recycled, after mechanical milling and crushing and re-introduced into the production process, without losing its mechanical behavior compared to "virgin" polystyrene. Ross and Evans (2003) showed that a recycling strategy for plastics significantly reduces the associated environmental cost of packaging material. Despite the high cost and complex logistics of building compacting machinery, as well as the difficulty of collecting waste polystyrene, this option should be an urgent priority.

Alternatively to EPS boxes, several materials with certain advantages have been proposed, such as the multiuse box, reusable HDPE box (Brox et al. 1984; Williams 2011), and biodegradable plastics/polymers. The last boxing option relates to the use of biodegradable plastics/polymers. However, most currently available plastics labelled as biodegradable, generally degrade under specific conditions that might not always be easy to find in the natural environment and can thus still harm ecosystems. Biodegradation in the marine environment is particularly challenging. In addition, plastics that are labelled "compostable" are not necessarily suitable for home composting. If compostable and conventional plastics are mixed in the recycling process, the quality of the resulting recyclates may be affected. For consumer applications, the existence of a well-functioning separate collection system for organic waste is therefore essential (EC 2018b). Nevertheless, all these fossil-based materials lack substantiation when the basic question is whether they contribute significantly to global warming reduction and specifically to GHG neutrality (or even close to this target).

The shelf-life of freshly packed seabass and meagre in polystyrene boxes can be extended up to 10 days (Trebar et al. 2015). The use of non-fossil-based materials could fulfil this requirement by retaining the same cool chain (Dieckmann et al. 2019). Although the most distant land freight transportation from Greece to any country in continental Europe is $72 \mathrm{~h}$, future works on assessing the comparative freshness of the products between polystyrene and corrugated boxes of different sizes at the delivery point would be of great value. Overall, the function of the 


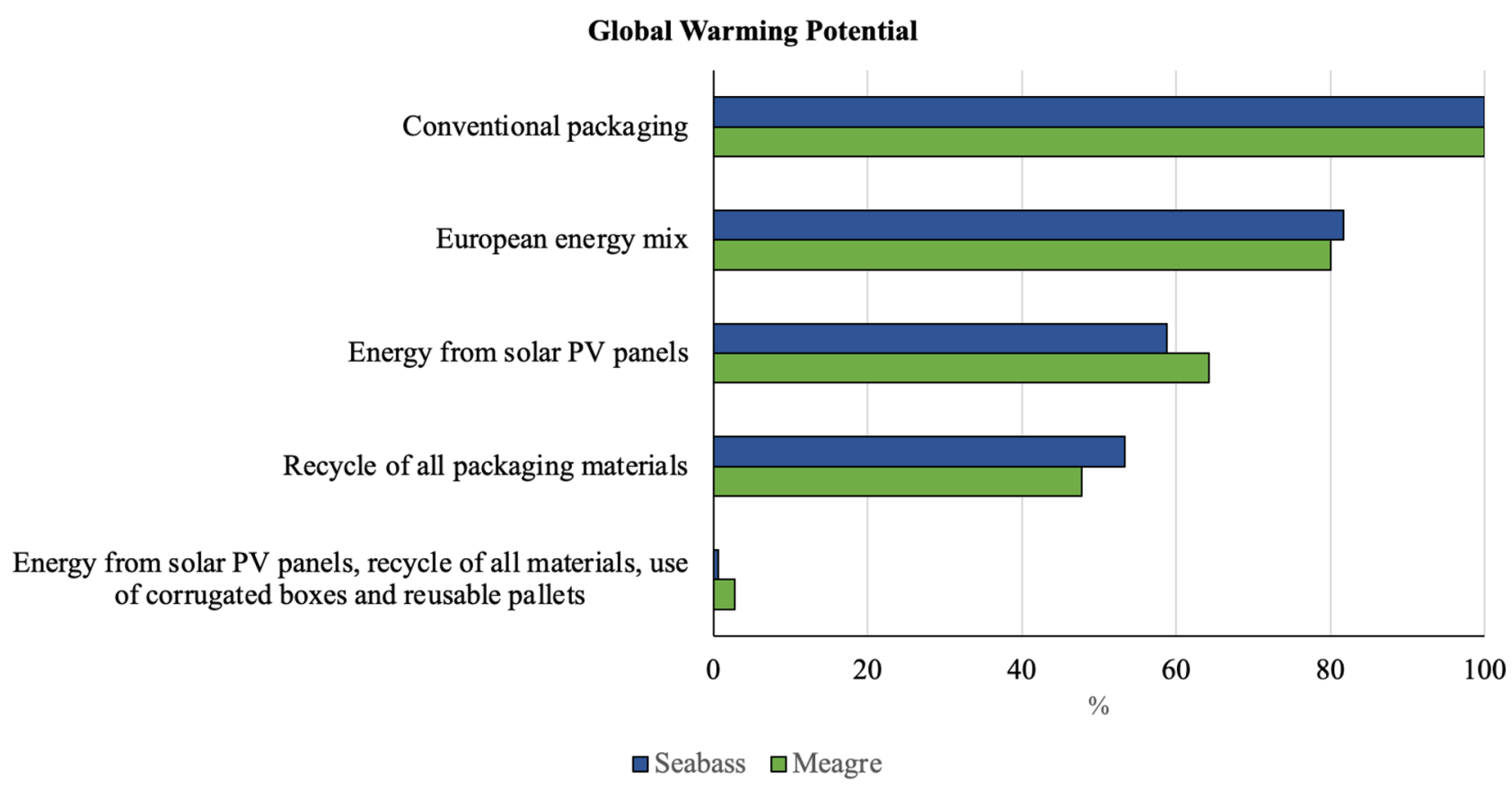

Fig. 7 Comparative global warming potential of seabass and meagre packaging under all applied scenarios

packaging stage (to extend shelf life, ensure hygiene and freshness, and facilitate transportation) can be fulfilled by using 10 and $20 \mathrm{~kg}$ boxes with a documented lower impact, as arising from this study. Moreover, converting the form of products, from fresh to frozen, could be another option aimed at avoiding the use of polystyrene boxes and allowing for marine transport instead of land/air freight (van Putten et al. 2016). Finally, the COVID-19 crisis showed that secondary processing and freezing of seabass, seabream, and meagre could be a valuable reserve-forming approach (EU 2013). In fact, many farms found it difficult to sell their market ready fish, which in turn affected the overall financial and production management of the farming sector.

Accordingly, future packaging processes will inevitably rely on materials and boxes offering GHG neutrality, which have recently be used, for example, in farmed salmon packaging (such as EcoFishBox ${ }^{\mathrm{TM}}$ ). This type of packaging box was actually assessed under scenario D, along with reusable and recyclable HDPE pallets. The practical advantages of these corrugated boxes, made of paper $(96 \%)$ and recyclable plastic (4\%), are related to lower labor, transportation, and recycling costs. Actually, the boxes are transported in the form of flat corrugated board sheets that are assembled manually or mechanically on-site, as needed, thus saving space also, in contrast to EPS poxes that need at least seven times more space for transport and storage (Stora Enso 2020). The reusable and recyclable HDPE pallets also have certain unique characteristics such as ease of cleaning, recycling by melting down, absence of porosity (and therefore inability to absorb and minimum risk of contamination) and a longer life span (Breezer et al. 1994). These advantages make them ideal for transportation of packaged fish. Concerning the old wooden pallets, Bengtsson and Logie (2015) have proposed disposal in landfill sites, in order to lock up the absorbed carbon dioxide, previously removed from the atmosphere by trees during growth. When corrugated boxes and reusable-recyclable HDPE pallets were combined with the use of solar energy and recycling of all other packaging materials, almost $100 \%$ of the $\mathrm{CO}_{2}$ neutrality target was achieved for seabass and more than 97\% for meagre. This signifies an outstanding environmentally friendly performance with significant benefits for the fish packaging sector. The difference observed for the "global warming" indicator is directly related to certain environmental requirements (i.e., emission rights), as well as to consumer awareness of ecological issues, as ecocertification is a serious advantage (Grankvist et al. 2004; Notarnicola et al. 2015). Moreover, this option is directly applicable without compromising the daily operation of the plants and may also have additional benefits in case of surplus solar energy sales.

The Paris Agreement and the EU Climate and Energy Framework set ambitious but necessary targets. Reducing GHG emissions by phasing out the technologies that rely on fossil fuels is one of the most important challenges, both currently and certainly in the near future. In the farmed 


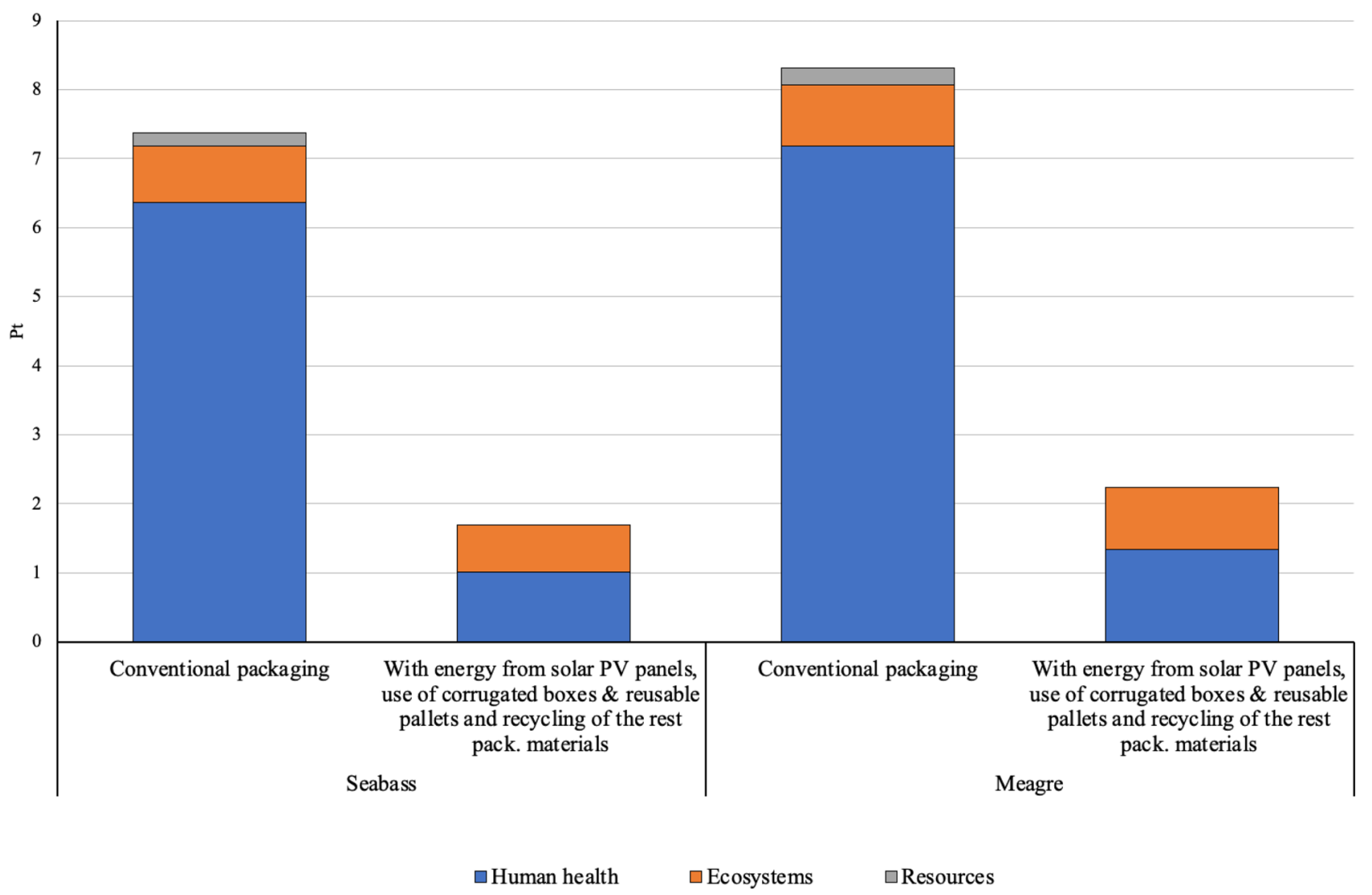

Fig. 8 LCA comparison of impacts on environmental indicators in seabass and meagre, between conventional packaging and under scenario D, using ReCiPe endpoint

fish packaging sector (and other sectors), the use of recycled or reusable non-fossil-based packaging materials (as described under scenario D) was documented as a decisive driver toward a drastic reduction of "global warming potential" (i.e., greater than $97 \%$ for both assessed fish species) and accordingly, achieving GHG neutrality. This scenario is readily applicable in the packaging process, given that the assessed non-fossil-based packaging materials are commercially available. This possibility is expected to be widely adopted by producers in the near future, given that the relevant legislative and consumer pressure will lead to stricter environmental standards.

The use of the midpoint method enabled the design of scenario $\mathrm{D}$ and calculation of the relevant impacts leading to $\mathrm{CO}_{2}$ neutrality and radically reducing GHG emissions. Moreover, the comparison of conventional packaging and scenario D using the endpoint calculation method, shed further light and clearly demonstrated the relative importance of impact categories, showing that the impacts related to "human health" were approximately 6 times lower under scenario $\mathrm{D}$, for both species.

\section{Conclusions and outlook}

The application of LCA to seabass and meagre packaging plants in western Greece revealed minor differences between the species, mainly related to their market size. The conventional packaging operation was related to ecological burdens concerning all major indicators of environmental damage with "marine" and "freshwater ecotoxicity" and "human carcinogenic toxicity" mostly affected, in particular. The applied alternative operation scenarios involving differentiation of the energy mix, use of solar energy and waste material recycling, significantly reduced most of the impacts to various degrees. However, each individual option failed to achieve zero or near-zero GHG emissions. This target was fulfilled by a combination of energy source alteration, recycling of packaging materials, use of non-fossil fuel based boxes and recyclable pallets. Moreover, this scenario not only succeeded in improving the overall ecological performance of the packaging systems (i.e., by benefiting most ecological impact indicators) but also stands out as a readily applicable proposal, without compromising the current operation of the plants. 
Strong evidence was provided that the use of electricity (and accordingly the impacts) during the packaging stage entails a significant source of impacts. Moreover, improvements such as the use of corrugated boxes (among others) led to better environmental performance of the packaging stage, can be applied quite fast and without creating operational obstacles to the packaging process. Alternative forms of product (i.e., processed and frozen) could also contribute to impact reduction. Finally, the current work documented the usefulness of the LCA method in environmental management and in the decision-making process in the fish packaging sector. Within this context, the achieved target of GHG emissions neutrality, which is directly related to the human health endpoint category, suggests that eco-efficiency is feasible in fish packaging and may contribute to the delivery of competitively priced goods and services that satisfy human needs and improve the quality of life.

Author contribution Evangelos Konstantinidis performed literature review, involved in data collection, conceived the methodology framework, and handled data analysis and visualization. Costas Perdikaris contributed to the interpretation of the results, assisted and provided inputs for the writing of the manuscript. Konstantinos Ganias coordinated data sampling, interpretation, and provided inputs for the writing.

\section{References}

Almeida C, Vaz S, Ziegler F (2015) Environmental life cycle assessment of a canned sardine product from Portugal. J Ind Ecol 19:607-617

Angelopoulos D, Doukas H, Psarras J, Stamtsis G (2017) Risk-based analysis and policy implications for renewable energy investments in Greece. Energy Policy 105:512-523

Avadí A, Bolaños C, Sandoval I, Ycaza C (2015) Life cycle assessment of Ecuadorian processed tuna. Int J Life Cycle Assess 20:1415-1428

Bengtsson J, Logie J (2015) Life cycle assessment of one-way and pooled pallet alternatives. Procedia CIRP 29:414-419

Bohnes FA, Laurent A (2019) LCA of aquaculture systems: methodological issues and potential improvements. Int J Life Cycle Assess 24:324-337

Boland MJ, Rae AN, Vereijken JM, Meuwissen MP, Fischer AR, van Boekel MA, Rutherfurd SM, Gruppen H, Moughan PJ, Hendriks WH (2013) The future supply of animal-derived protein for human consumption. Trends Food Sci Tech 29:62-73

Breezer HW, Pintar TM, Wolfe MJ (1994) U.S. Patent No. 5,351,628. Washington, DC: U.S. Patent and Trademark Office

Brems A, Baeyens J, Dewil R (2012) Recycling and recovery of postconsumer plastic solid waste in a European context. Therm Sci 16:669-685

Brox J, Kristiansen M, Myrseth A, Aasheim PW (1984) Planning and engineering data. 4. Containers for fish handling. Food and Agriculture Organization of the United Nations, Fisheries Circular 773, $58 \mathrm{p}$

Buchspies B, Tölle SJ, Jungbluth N (2011) Life cycle assessment of high-sea fish and salmon aquaculture. ESU-services Ltd., fair consulting in sustainability, Uster, Switzerland. http://www.armeris. fr/downloads/fuel/buchspies_tolle-jungbluth_2011.pdf. Accessed 2 Oct 2019
Cao L, Diana JS, Keoleian GA, Lai Q (2011) Life cycle assessment of Chinese shrimp farming systems targeted for export and domestic sales. Environ Sci Tech 45:6531-6538

Claussen IC, Indergård E, Grinde M (2011) Comparative Life Cycle Assessment (LCA) of production and transport of chilled versus superchilled haddock (Melanogrammus aeglefinus) fillets from Norway to France. Procedia Food Sci 1:1091-1098

Coulomb D (2008) Refrigeration and cold chain serving the global food industry and creating a better future: two key IIR challenges for improved health and environment. Trends Food Sci Tech 19:413-417

Dieckmann E, Nagy B, Yiakoumetti K, Sheldrick L, Cheeseman C (2019) Thermal insulation packaging for cold-chain deliveries made from feathers. Food Packag Shelf Life 21:100360

Driscoll J, Boyd C, Tyedmers P (2015) Life cycle assessment of the Maine and southwest Nova Scotia lobster industries. Fish Res 172:385-400

Eilertsen AB (2012) Improved automated singulation of pelagic fish: Novel engineering and prior art construction-Design, Analysis and ecperiments (Master's thesis) Norwegian University of Science and Technology. Trondheim, Norway

European Commission - Joint Research Centre - Institute for Environment and Sustainability (2011) International Reference Life Cycle Data System (ILCD) Handbook- Recommendations for Life Cycle Impact Assessment in the European context. First edition (2011) EUR 24571 EN. Publications Office of the European Union, Luxemburg, p 145

European Commission (EC) (2018a) Communication from the commission to the European parliament, the European Council, the Council, the European economic and social committee, the committee of the regions and the European investment bank. A Clean Planet for all. A European strategic long-term vision for a prosperous, modern, competitive and climate neutral economy. Brussels, COM/2018/773 final

European Commission (EC) (2018b) A European strategy for plastics in a circular economy. https://ec.europa.eu/environment/ circular-economy/pdf/plastics-strategy-brochure.pdf. Accessed 2 Oct 2019

European Manufacturers of Expanded Polystyrene (EUMEPS) (2009) What is EPS? https://eumeps.construction/product/whatis-eps. Accessed 20 Aug 2019

European Union (EU) (2013) Regulation (EU) No 1379/2013 of the European Parliament and of the Council of 11 December 2013 on the common organization of the markets in fishery and aquaculture products, amending Council Regulations (EC) No 1184/2006 and (EC) No 1224/2009 and repealing Council Regulation (EC) No 104/2000 (OJ L 354, 28.12.2013, p. 1)

Eurostat (2019) Energy balance sheets 2017 data (2019 edition). Publications Office of the European Union, Luxenburg, p 236

Evans S, Pidcock R (2015) COP21: Experts discuss 'greenhouse gas emissions neutrality'. Carbon Brief

FAO (2016) Bio-based food packaging in sustainable development. Challenges and opportunities to utilize biomass residues from agriculture and forestry as a feedstock for bio-based food packaging. Forestry Policy and Resources Division, Forest Products Team. http://www. fao.org/forestry/45849-023667e93ce5f79f4df3c74688c2067cc.pdf. Accessed 2 June 2020

FAO (2018) The State of World Fisheries and Aquaculture 2018 Meeting the sustainable development goals. Rome. License: CC BY-NC-SA 3.0 IGO

Federation Greek Maricultures (FGM) (2020) Greek aquaculture 2020 (annual report). 64 p (in Greek)

Fthenakis VM, Kim HC, Alsema E (2008) Emissions from photovoltaic life cycles. Environ Sci Tech 42:2168-2174

Godfray HCJ, Beddington JR, Crute IR, Haddad L, Lawrence D, Muir JF, Pretty J, Robinson S, Thomas SM, Toulmin C (2010) 
Food security: the challenge of feeding 9 billion people. Science 327:812-818

Grankvist G, Dahlstrand U, Biel A (2004) The impact of environmental labelling on consumer preference: Negative vs. positive labels. J Consum Policy 27:213-230

Gronroos J, Seppala J, Silvenius F, Makinen T (2006) Life cycle assessment of Finnish cultivated rainbow trout. Boreal Environ Res 11:401-414

Hall M (2011) Fish processing: sustainability and new opportunities. Wiley-Blackwell, UK

Hallström E, Bergman K, Mifflin K, Parker R, Tyedmers P, Troell M, Ziegler F (2019) Combined climate and nutritional performance of seafoods. J Clean Prod 230:402-411

Heikkinen M, Nurminen V, Hiltunen T, Hiltunen Y (2008) A modeling and optimization tool for the expandable polystyrene batch process. Chem Prod Process Model 3:1934-2659

Henningsson S, Hyde K, Smith A, Campbell M (2004) The value of resource efficiency in the food industry: A waste minimisation project for East Anglia, UK. J Clean Prod 12:505-512

Hospido A, Vazquez ME, Cuevas A, Feijoo G, Moreira MT (2006) Environmental assessment of canned tuna manufacture with a lifecycle perspective. Resour Conserv Recycl 47:56-72

Huijbregts MA, Steinmann ZJ, Elshout PM, Stam G, Verones F, Vieira M, Zijp M, Hollander A, van Zelm R (2016) ReCiPe 2016. A harmonized life cycle impact assessment method at midpoint and endpoint level. Report I: characterization. RIVM Report 20160104. National Institute for Human Health and the Environment, Bilthoven

Iribarren D, Moreira MT, Feijoo G (2010) Life Cycle Assessment of fresh and canned mussel processing and consumption in Galicia (NW Spain). Resour Conserv Recycl 55:106-117

Iribarren D, Moreira MT, Feijoo G (2012) Life cycle assessment of aquaculture feed and application to the turbot sector. Int J Environ Res 6:837-848

ISO (2006a) ISO 14040:2006 Environmental management - life cycle assessment - principles and framework. Switzerland, Geneva

ISO (2006b) ISO 14044:2006 environmental management - life cycle assessment - requirements and guidelines. Switzerland, Geneva

Jambeck JR, Geyer R, Wilcox C, Siegler TR, Perryman M, Andrady A, Narayan R, Law KL (2015) Plastic waste inputs from land into the ocean. Science 347:768-771

Konstantinidis E, Perdikaris C, Batzios C, Michaelidis B, Ganias K (2019) Life-cycle assessment as a method to identify environmental impacts in the Mediterranean aquaculture industry. Proceedings of the 14th International Congress on the Zoogeography and Ecology of Greece and Adjacent Regions. Thessaloniki, Greece. p 86

Konstantinidis E, Perdikaris C, Ganias K (2021) Life cycle assessment of seabass and meagre in marine cage farming: from feeding plant to harvesting. Med Mar Sci 22:125-136

Laso J, Margallo M, Fullana P, Bala A, Gazulla C, Irabien A, Aldaco $R$ (2017) Introducing life cycle thinking to define best available techniques for products: application to the anchovy canning industry. J Clean Prod 155:139-150

Leceta I, Guerrero P, Cabezudo S, de la Caba K (2013) Environmental assessment of chitosan-based films. J Clean Prod 41:312-318

Levin K, Song J, Morgan J (2015) COP21 Q\&A: what is GHG emissions neutrality in the context of the Paris Agreement? World Resources Institute, Washington D.C

Marel (2012) Farmed fish packing grading and batching into fixed-weight packs. https://marel.com/media/53753/farmedfishpacksolution_ 2012 lores.pdf. Accessed 2 June 2020

Margeirsson B, Smárason BÖ, Pórðarson G, Ólafsdóttir A, Reynisson E, Gestsson Ó, Arason S (2012) Comparison of transport modes and packaging methods for fresh fish products-storage life study and life cycle assessment. Report 35-12. Icelandic Food and Biotech
R\&D, Reykjavík. http://www.matis.is/media/matis/utgafa/35-12_ Comparison-of-transport-modes.pdf. Accessed 2 Oct 2019

Mungkung R, Gheewala SH (2007) Use of life cycle assessment (LCA) to compare the environmental impacts of aquaculture and agri-food products. In: Bartley D, Brugère $\mathrm{C}$, Soto $\mathrm{D}$, Gerber $\mathrm{P}$, Harvey $\mathrm{B}$ (ed) Comparative assessment of the environmental costs of aquaculture and other food production sectors: methods for meaningful comparisons. FAO/WFT Expert Workshop. FAO Fisheries Proceedings, Vancouver, Canada. FAO Rome 10:87-96

North EJ, Halden RU (2013) Plastics and environmental health: the road ahead. Rev Environ Health 28:1-8

Notarnicola B, Tassielli G, Renzulli PA, Guidice AL (2015) Life cycle assessment in the agri-food sector: an overview of its key aspects, international initiatives, certification, labelling schemes and methodological issues. In: Notarnicola B, Salomone R, Petti L, Renzulli PA, Roma R, Cerutti AK (eds) Life cycle assessment in the agri-food sector: case studies, methodological issues and best practices. Springer, pp 1-56

Parker R (2018) Implications of high animal by-product feed inputs in life cycle assessments of farmed Atlantic salmon. Int J Life Cycle Assess 23:982-994

Pelletier N, Ayer N, Tyedmers P, Kruse S, Flysjo A, Robillard G, Ziegler F, Scholz A, Sonesson U (2007) Impact categories for life cycle assessment research of seafood production: Review and prospectus. Int J Life Cycle Assess 12:414-421

Pelletier N, Tyedmers P (2010) Life cycle assessment of frozen tilapia fillets from Indonesian lake-based and pond-based intensive aquaculture systems. J Ind Ecol 14:467-481

Rajendran S, Scelsi L, Hodzic A, Soutis C, Al-Maadeed MA (2012) Environmental impact assessment of composites containing recycled plastics. Resour Conserv Recycl 60:131-139

Roadmap for Carbon Neutrality (RNC) 2050 (2019) Long-term strategy for Carbon neutrality of the Portuguese economy by 2050. Republica Portugeusa

Roma R, Corrado S, De Boni A, Forleo BM, Fantin V, Moretti M, Palmieri N, Vitali A, De Camillis C (2015) Life cycle assessment in the livestock and derived edible products sector. In: Notarnicola B, Salomone R, Petti L, Renzulli AP, Roma R, Cerutti KA (eds) Life cycle assessment in the agri-food sector: Case studies, methodological issues and best practices. Springer. pp 251-332

Ross S, Evans D (2003) The environmental effect of reusing and recycling a plastic based packaging system. J Clean Prod 11:561-571

Samper MD, Garcia-Sanoguera D, Parres F, Lopez J (2010) Recycling of expanded polystyrene from packaging. Prog Rubber Plast Re 26:83-92

Saraiva AB, Pacheco EB, Gomes GM, Visconte LL, Bernardo CA, Simões CL, Soares AG (2016) Comparative lifecycle assessment of mango packaging made from a polyethylene/natural fiber-composite and from cardboard material. J Clean Prod 139:1168-1180

Scarborough P, Appleby PN, Mizdrak A, Briggs AD, Travis RC, Bradbury KE, Key TJ (2014) Dietary greenhouse gas emissions of meat-eaters, fish-eaters, vegetarians and vegans in the UK. Clim Change 125:179-192

Silvenius F, Grönroos J, Kankainen M, Kurppa S, Mäkinen T, Vielma J (2017) Impact of feed raw material to climate and eutrophication impacts of Finnish rainbow trout farming and comparisons on climate impact and eutrophication between farmed and wild fish. J Clean Prod 164:1467-1473

Siracusa V, Rocculi P, Romani S, Dalla Rosa M (2008) Biodegradable polymers for food packaging: A review. Trends Food Sci Tech 19:634-643

Siracusa V, Ingrao C, Giudice AL, Mbohwa C, Dalla Rosa M (2014) Environmental assessment of a multilayer polymer bag for food packaging and preservation: An LCA approach. Food Res Int 62:151-161

Stora Enso (2020) EcoFishBox ${ }^{\mathrm{TM}}$ leaflet. Division Packaging Solutions, Jönköping, Sweden. https://cdn2.hubspot.net/hubfs/4056792/ 
Packaging\%20Solutions/Norway/StoraEnso_Ecofishbox-brochurelowres.pdf. Accessed $01 \mathrm{Feb} 2020$

Svanes E, Vold M, Hanssen OJ (2011) Effect of different allocation methods on LCA results of products from wild-caught fish and on the use of such results. Int J Life Cycle Assess 16:512-521

Tan RBH, Khoo HH (2005) Life cycle assessment of EPS and CPB inserts: design considerations and end of life scenarios. J Environ Manage 74:195-205

Thrane M, Nielsen EH, Christensen P (2009) Cleaner production in Danish fish processing - Experiences, status and possible future strategies. J Clean Prod 17:380-390

Tilman D, Clark M (2014) Global diets link environmental sustainability and human health. Nature 515:518-522

Trebar M, Lotrič M, Fonda I (2015) Use of RFID temperature monitoring to test and improve fish packing methods in styrofoam boxes. J Food Eng 159:66-75

van Putten IE, Farmery AK, Green BS, Hobday AJ, Lim-Camacho L, Norman-López A, Parker RW (2016) The environmental impact of two Australian rock lobster fishery supply chains under a changing climate. J Ind Ecol 20:1384-1398

Vázquez-Rowe I, Moreira MT, Feijoo G (2010) Life cycle assessment of horse mackerel fisheries in Galicia (NW Spain): comparative analysis of two major fishing methods. Fish Res 106:517-527

Vázquez-Rowe I, Moreira MT, Feijoo G (2011) Life Cycle Assessment of fresh hake fillets captured by the Galician fleet in the Northern Stock. Fish Res 110:128-135

Wernet G, Bauer C, Steubing B, Reinhard J, Moreno-Ruiz E, Weidema B (2016) The Ecoinvent database version 3 (part I): overview and methodology. Int J Life Cycle Assess 21:1218-1230
Wikström F, Williams H, Verghese K, Clune S (2014) The influence of packaging attributes on consumer behaviour in food-packaging life cycle assessment studies-a neglected topic. J Clean Prod 73:100-108

Williams KS (2011) Life cycle assessment of bulk packaging used to transport fish products: Case study. In: Hall GM (ed) Fish processing: sustainability and new opportunities. Blackwell Publishing Ltd, West Sussex, UK, pp 266-287

World Cancer Research Fund/American Institute for Cancer Research (WCRF/AICR) (2018) Continuous Update Project Expert Report 2018. Meat, fish and dairy products and the risk of cancer. In: Diet, nutrition, physical activity and cancer: a global perspective. Continuous Update Project Expert Report. https://www.wcrf.org/ sites/default/files/Meat-Fish-and-Dairy-products.pdf. Accessed 29 Aug 2019

Zampori L, Dotelli G (2014) Design of a sustainable packaging in the food sector by applying LCA. Int J Life Cycle Assess 19:206-217

Ziegler F, Emanuelsson A, Eichelsheim JL, Flysjö A, Ndiaye V, Thrane M (2011) Extended life cycle assessment of southern pink shrimp products originating in Senegalese artisanal and industrial fisheries for export to Europe. J Ind Ecol 15:527-538

Ziegler F, Nilsson P, Mattsson B, Walther Y (2003) Life Cycle assessment of frozen cod fillets including fishery-specific environmental impacts. Int J Life Cycle Assess 8:39-47

Publisher's Note Springer Nature remains neutral with regard to jurisdictional claims in published maps and institutional affiliations. 